\title{
An appreciation
}

\author{
HAMISH NISBET MUNRO
}

(3 July 1915-28 October 1994)

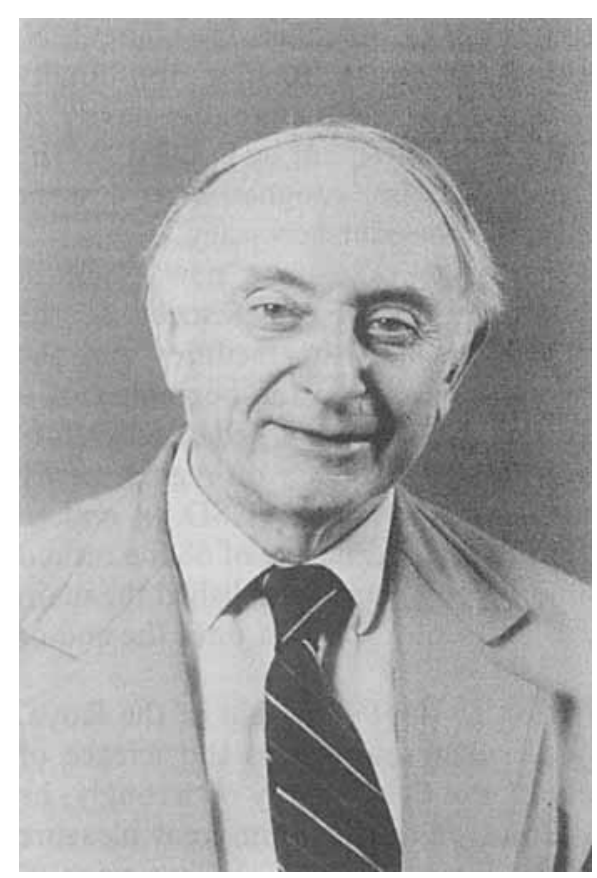

One of Hamish Munro's most notable characteristics as a scientist was his sense of history. In a classic review he traced the history of protein metabolism from the early discoveries of Black and Lavoisier, the founding fathers of the science of nutrition, down to the present day (Munro, 1964) and in a later paper (Munro, 1986) he modestly described his own place in that family tree.

This interest in history was complemented by a broad biological outlook; he looked at his own research on mammals in the context of the whole animal kingdom and of the evolutionary process that has shaped our nutritional needs.

We may also look at Munro's place in history from a different perspective: his ancestry and genetic endowment. The Munro clan occupied territory in the north-eastern highlands of Scotland, from the slopes of Ben Wyvis to the North Sea. One branch became fervid Protestants and in 1630 Alexander Munro produced a translation of the Bible in Gaelic. Four Munro brothers fought with Cromwell and after the Restoration were deported to New England. There they seem to have flourished; one Ebenezer Munro of Concord, Massachusetts, claimed to have fired the first shot in the War of American Independence. Another of this branch, having added an ' $\mathrm{e}$ ' to his name, became President of the USA and fathered the famous Munroe Doctrine. It is perhaps not too fanciful to suppose that from this tribal ancestry Hamish inherited two characteristics: great talent in several fields and a fighting spirit that, in spite of increasing disability, sustained him in research almost to the end of his life.

Hamish was born in Edinburgh in 1915, where his father worked as a banker. When he was 8 years old the family moved back to the Highlands; Hamish was educated in the village school, with one room, one teacher and six separate classes. Nevertheless, he became as proficient in Latin as any product of the public school system, an accomplishment of which he was rather proud. He developed an interest in the structure of language and linguistics and began to study Anglo-Saxon and medieval English. Hamish had a good ear for music (he was an accomplished pianist) which enabled him to learn languages quickly and in later life to give scientific seminars in French, German and Italian. He even acquired a little Estonian from talking with Estonian patients during the war.

From school Hamish went to the University of Glasgow, where he began by taking a BSc in physiology, which he passed with first-class honours. He graduated in medicine in 1939. For 5 years during the war he held the post of Clinical Tutor at the Glasgow Victoria 
Infirmary, a 500-bed hospital, where, in addition to his other duties, he ran the venereal diseases clinic, the blood transfusion service and the pathology department. In spite of this huge workload Hamish found time for research and obtained a grant from the Medical Research Council (MRC) for studies on metabolic responses to injury under David Cuthbertson. This work led to an interest in the effect of vitamin-C deficiency on capillary fragility and wound healing. In gaining access to patients with scurvy he met Edith Little, a physician at another leading hospital, and they were married in 1946.

After the war Hamish started his academic career as Lecturer in Physiology at Glasgow. After 2 years he transferred to the newly created Department of Biochemistry under J. N. Davidson, where he rose progressively from Senior Lecturer to Reader and finally Professor. Towards the end he clearly felt unhappy in that department, and after nearly 20 years in it began to look for fresh openings. After Kodicek's retirement he applied for the post of Director of the Dunn Nutrition Unit at Cambridge, but resigned after 1 week because the MRC would not give him the facilities that he thought necessary.

The turning point came in 1966, when he was invited to take up a new Chair in Physiological Chemistry in the Department of Nutrition and Food Science at the Massachusetts Institute of Technology (MIT). At MIT he had the facilities and the stimulus for an almost explosive expansion of his work; it was also the beginning of a collaboration over many years with Vernon Young. In 1980 he was appointed concurrently to the federal post of director of the Human Nutrition Research Center on Aging, newly established at Tufts University by the US Department of Agriculture (USDA), and to professorships of medicine and nutrition at Tufts. After 3 years, at the age of 68, he retired from the directorship of the Center, having seen its building go up and established the main lines of its research programme, but he remained there as a senior scientist until the end of his working life.

Hamish's contributions were recognized by his election to the Fellowship of the Royal Society of Edinburgh at the early age of 41 . It was a great set-back to the science of nutrition that he was not elected to the Royal Society of London; rightly or wrongly, he attributed this to the opposition of J. N. Davidson. However, it gave him great pleasure when in 1985 he was made an honorary Fellow of the Royal College of Physicians of London. In America, soon after he had obtained US citizenship, he was elected to the National Academy of Sciences. He was given successively: the Osborne and Mendel and Borden Awards of the American Institute of Nutrition; the Bristol-Myers Award for achievement in Nutrition Research, and an award by the Rank Prize Funds for his work 'towards increasing man's understanding of the biochemical effects and implications of nutritional change'.

These are the bare bones of a distinguished career. Hamish's move to MIT made it possible for his research to develop to its full, but it took a toll on his domestic life. In the 1970s his family mostly returned to Britain, the children to complete their education and Edith to re-train as a psychiatrist, so that Hamish had to commute from Boston most weekends. It was obvious to his friends that he relied a great deal on Edith and was proud of her career. When she died after a short illness in 1987 he was never quite the same again and retreated more and more into the laboratory, spending very little time in his solitary flat in Concord Avenue, although he was always generous in receiving and entertaining old friends.

Hamish's literary output was prodigious, more than 700 papers and reviews. It is said that in 1983 he wrote his MD thesis, which won a gold medal, in 2 weeks. He never took a PhD and until then had contented himself with a DSc. Although he edited or co-edited many multi-author books, it is sad that he left no book entirely of his own in which he could set out, at greater length than was possible in a short review, his scientific philosophy. 
However, he will always be remembered for his four volumes entitled Mammalian Protein Metabolism. The first two, edited jointly with J. B. Allison, appeared during his time in Glasgow; the other two in 1970, after Allison's death. The four volumes include forty-five chapters of which eight were written by Munro alone. These chapters are his memorial; they contain an enormous amount of information covering a very wide range and they have stood the test of time. Even now, after some 30 years, I find myself consulting them frequently for information that cannot easily be found anywhere else. That is remarkable in these days when the literature is expanding so rapidly. Moreover, they remind us that, even in scientific writing, style, as well as information, is important.

Except for Vernon Young, Hamish had no senior colleagues who worked with him continuously for many years. Almost all his research was done in collaboration with successive generations of doctoral students and post-doctoral fellows. It is a measure of his powers of leadership and inspiration that there never seems to have been a shortage of people wanting to join his laboratory. His collaborators are now scattered all over the world, many of them in senior positions in biochemistry and nutrition, so that his influence has been widely diffused. By the same token, it is impossible in a short memoir to give due credit to all those who shared in his discoveries.

Throughout his life Hamish never lost sight of the practical problems of human nutrition; the need for basic science to contribute to the improvement of nutritional health, and for studies at the molecular level to enlarge our understanding of how metabolic processes are integrated in the whole animal.

He did not hesitate to give his time to innumerable international and national committees, British and American, concerned with nutrition and health. His special interest was in protein requirements and he made important contributions to the Expert Groups of the Food and Agriculture Organization and the World Health Organization on Energy and Protein Requirements which met in 1963, 1971 and 1981. When he became director of the USDA Human Nutrition Research Center on Aging, high on the agenda was the protein requirement of the elderly and the biological factors that determine it.

After this short account of the events of Hamish's life, I come now to his research. His life-long interest was in protein metabolism. He traces his scientific heritage from Voit through Cathcart and Cuthbertson. While still a medical student he worked under Cuthbertson on the effect of overfeeding on protein metabolism; four papers on this were published in the Biochemical Journal in 1937. After the war he returned to the study of energy-protein relationships and showed that energy balance is always a factor in $\mathrm{N}$ balance, carbohydrate being rather more important than fat. Although measurements of insulin were not possible in those days, his concept of insulin 'driving' amino acids into muscle protein opened up the whole field of hormonal control of protein metabolism. His article in Physiological Reviews in 1951 entitled 'Carbohydrate and fat as factors in protein utilisation and metabolism' was a very important survey of this research; it certainly had a profound effect on my work because of its implications for understanding protein-energy deficiency states in man. His DSc, obtained in 1956, was for studies on the influence of certain nutritional factors on the course of protein metabolism.

In the 1950s isotopically-labelled amino acids were becoming available and it was a logical next step to look at the uptake of $\left[{ }^{14} \mathrm{C}\right]$ glycine into proteins under various conditions. For one working in Davidson's laboratory, it was natural also to examine the synthesis of RNA, and the effect of dietary conditions on the aggregation of rRNA in polysomes. With Adam Fleck he developed a definitive method of measuring RNA. This line of work could be regarded as the starting-point for a shift in Hamish's main research interest from the whole animal to the regulation of protein metabolism at the molecular level. The new development was vigorously continued after Hamish's move to MIT; he 
showed that fasting causes increased breakdown of rRNA and releases a flood of nucleotides which inhibit de novo synthesis of purine bases. The research that followed focused on regulation of the synthesis of two particular proteins, albumin and ferritin. Albumin, so widely, though not always appropriately, used as a marker of the state of protein nutrition in man, provided a link between Hamish's interest in molecular mechanisms and his continuing concern for practical human problems such as protein requirements and the effects of ageing; ferritin provided an ideal model for studies on protein synthesis because in the liver it is rapidly induced by $\mathrm{Fe}$ to reach concentrations several times the basal level. The work on albumin provided the earliest evidence that this protein is synthesized exclusively by membrane-bound ribosomes, and that albumin mRNA could be isolated exclusively from bound but not from free ribosomes, thus ending a controversy in the literature. It was shown that the production of export proteins in the liver is under dietary control through changes in the concentration of mRNA. A method was developed for measuring the rate of albumin synthesis in vivo with $\left[{ }^{15} \mathrm{~N}\right] \mathrm{glycine}$; the labelling of urea could be used as a measure of the precursor enrichment of arginine taken up into albumin. By this method Hamish and his co-workers showed that the elderly, in contrast to younger adults, do not respond to an increase in dietary protein with a rise in albumin synthesis.

The work on ferritin synthesis, started with Drysdale in the 1960s, became his main interest in the later years of his career. In contrast to albumin, ferritin is made by free polyribosomes, suggesting the generalization that secreted proteins are synthesized by membrane-bound ribosomes, retained proteins by free ribosomes. The induction of protein synthesis was shown to be a remarkable example of translational control; in the noninduced state there is a substantial pool of free mRNA for both heavy and light chains of ferritin, which, on stimulation by $\mathrm{Fe}$, are taken up into polysomes and become translatable. In the unstimulated state a repressor protein is bound to a highly conserved sequence in the untranslated region of ferritin mRNA; on administration of $\mathrm{Fe}$ this protein is released and translation of the stored mRNA can go forward. These findings led to work on the secondary structure of the regions in ferritin mRNA that are important for the binding of the regulatory protein. The advantage of this translational control is that it allows a very rapid coordinated response to a potentially toxic load of free $\mathrm{Fe}$. In addition, there is a certain amount of transcriptional control of the production of ferritin messenger, but this operates over a longer time span. In the last stages of his research on ferritin Hamish calculated from the amino acid sequences of the two ferritin sub-units in different mammals that they had evolved from a single ancestral protein approximately 350 million years ago, about the time of divergence of the $\alpha$ - and $\beta$-globins of haemoglobin.

From these examples one can trace the way in which Hamish's research on protein metabolism developed step by step over 50 years, and it makes a remarkably coherent and interesting story.

Several other lines of research branched off this main trunk. The best known is probably his studies with Vernon Young on 3-methylhistidine (3MH). They first showed that 3MH is produced by post-translational methylation of histidine; the 3MH does not charge tRNA in muscle, and when ${ }^{14} \mathrm{C}$-labelled $3 \mathrm{MH}$ is injected it is quantitatively excreted. Since most of the $3 \mathrm{MH}$ in the body is in skeletal muscle, the urinary excretion of this compound can be used as a measure of the rate of muscle-protein breakdown. Although the presence of small amounts of $3 \mathrm{MH}$ in other tissues with more rapid turnover rates means that its output cannot be attributed entirely to muscle-protein turnover, the 'test' has been quite widely used as a measure of catabolic stress.

Another sideline, developed in conjunction with R. J. Wurtman of MIT, was concerned with amino acid supply and brain neurotransmitters. The most interesting outcome of this 
work was the finding that tryptophan, the rate-limiting precursor of serotonin (5hydroxytryptamine), enters the brain in competition with the branched-chain amino acids; entry is increased after a carbohydrate meal, and in the encephalopathy of liver cirrhosis excessive amounts of tryptophan enter and the resulting serotonin contributes to the development of hepatic coma.

A third topic on which Hamish embarked soon after arriving at MIT was concerned with nutritional effects on the growth of the placenta and its capacity for protein synthesis. A novel video-scanning method was developed for quantitating the main morphological features of the placenta, and it was shown that the low birth weight of infants in Guatemala was associated with a great reduction in the surface area of the placenta available for nutrient transport and secretion of peptide hormones. A great deal of work followed on factors that determine the production of placental lactogen and chorionic gonadotropin and their relationship to the somatomedin hormones. It appeared that protein intake controls the release of placental lactogen, which in turn regulates somatomedin output in mother and fetus. This body of work is clearly of great relevance to the problems of fetal development and low birth weight in the Third World. Any one of these subjects that I have called sidelines would, for many scientists, have provided a programme of research that lasted a lifetime.

That is an appropriate note on which to end. Hamish's contribution may be summarized in one phrase: he brought nutrition to the molecular level without ignoring its fundamental importance for the whole individual and for human health.

\section{J. C. WATERLOW}

I am grateful to Professors Adam Fleck, Donald Naismith and Alan Shenkin for helpful comments, and to Dr Adrian Bomford for permission to draw on his excellent obituary in the Independent.

\section{REFERENCES}

Munro, H. N. (1964). A historical introduction: the origin and growth of our present concepts of protein metabolism. In Mammalian Protein Metabolism, vol. 1, pp. 1-34. New York and London: Academic Press.

Munro, H. N. (1986). Back to basics: an evolutionary odyssey with reflections on the nutrition research of tomorrow. Annual Review of Nutrition 6, 1-12. 